\title{
PENGELOLAAN SEDIAAN OBAT PADA LOGISTIK FARMASI RUMAH SAKIT UMUM TIPE B DI JAWA TIMUR
}

\author{
MANAGING DRUGS SUPPLY IN PHARMACY LOGISTIC \\ OF PUBLIC HOSPITAL TYPE B IN EAST JAVA
}

Stella Herliantine Febreani, Djazuly Chalidyanto

Fakultas Kesehatan Masyarakat, Universitas Airlangga, Surabaya

E-mail: stellaherliantine@gmail.com

\begin{abstract}
Inventory control of drugs in hospital which are not done properly can cause stockout or stagnant of supplies. Based of data processing of the drug at Siti Khodijah Sepanjang Hospital experienced stagnant amount $38,9 \%$ and stockout amount 29,3\% during period January-September 2015. The objectives of the study were to analysis inventory control of drug in logistic pharmacy Siti Khodijah Sepanjang Hospital. This research was a descriptive research with cross sectional design by observation and interviews. Indepth interviews were carried out to get more detailed information about the variables examined. Activity of planning, procurement, distribution, and storage are performed not effective enough so led to stagnant and stockout drug. Also evaluation that has running was not adequate because only looks about financial audit. The conclusion that can be drawn is logistic management system has not run effectively so that the occurrence so stagnant and stockout drug.
\end{abstract}

Keywords: drug stagnant and stockout, hospital, inventory control, logistic management

\section{PENDAHULUAN}

Manajemen logistik obat merupakan hal yang sangat penting bagi rumah sakit karena persediaan obat yang terlalu besar maupun terlalu sedikit akan membuat rumah sakit mengalami kerugian. Kerugian yang didapat berupa biaya persediaan obat yang membesar serta terganggunya kegiatan operasional pelayanan (Verawaty. dkk, 2010). Dampak negatif secara medis maupun ekonomis akan dirasakan rumah sakit jika terjadi ketidakefektifan dalam melakukan manajemen obat (Anshari, 2009). Seperti penelitian yang telah dilakukan Mellen 2012 di RSU Haji Surabaya bahwa kondisi stagnant dan stockout obat dapat menimbulkan kerugian cukup besar yang harus ditanggung Rumah Sakit.

Rumah Sakit Siti Khodijah Sepanjang merupakan salah satu Rumah Sakit tipe B dan merupakan salah satu amal usaha kesehatan milik Muhammadiyah.Pengelolaan sediaan farmasi obat RS Siti Khodijah Sepanjang ditangani oleh Instalasi
Farmasi dimana terdiri dari dua unit yakni logistik dan depo farmasi.penelitian ini fokus terhadap pengelolaan sediaan farmasi obat pada logistik farmasi. Berdasarkan pengelolaan data persediaan obat pada Logistik Instalasi Farmasi Rumah Sakit SIti Khodijah Sepanjang dengan Analisis ABC didapatkan rata-rata kejadian stagnant sebesar $38.9 \%$ dan rata-rata kejadian stockout sebesar 29,3\% dalam periode Januari hingga September 2015. Penelitian ini bertujuan untuk menganalisis sistem pengelolaan sediaan farmasi obat pada logistik farmasi RS Siti Khodijah Sepanjang. Hasil penelitian diharapkan mampu memberikan rekomendasi perbaikan pengelolaan sediaan farmasi obat yang mana dapat meningkatkan efisiensi dan menurunkan cost rumah sakit.

\section{PUSTAKA}

Instalasi Farmasi Rumah Sakit memberikan pelayanan kefarmasian yang terdiri atas pelayanan 
paripurna berupa perencanaan, pengadaan, produksi, penyimpanan perbekalan kesehatan atau sediaan farmasi, distribusi obat, penggunaan obat dan pengendalian mutu (Siregar, 2004).Pelayanan kefarmasian bersifat manajerial yakni disebut dengan pengelolaan perbekalan sediaan farmasi yang mana berupa siklus.Siklus pengelolaan perbekalan sediaan farmasi yakni terdiri dari perencanaan, pengadaan, penerimaan, penyimpanan, pendistribusian, pemusnahan dan penarikan, serta administrasi yang berisi pencatatan dan pelaporan (Peraturan Menteri Kesehatan No. 58 Tahun 2014).

\section{Perencanaan Obat}

Perencanaan merupakan kegiatan dalam menentukan jumlah dan periode pengadaan sediaan farmasi, alat kesehatan, dan bahan medis habis pakai sesuai dengan hasil kegiatan pemilihan untuk menjamin terpenuhinya kriteria tepat jenis, tepat jumlah, tepat waktu dan efisien (Permenkes, 2014).

\section{Pengadaan Obat}

Pengadaan adalah suatu kegiatan untuk memenuhi kebutuhan obat sesuai dengan kebutuhan operasional yang telah ditetapkan di dalam proses perencanaan (Permenkes, 2014) Pengadaan obat memiliki tiga syarat penting yang harus dipenuhi, antara lain: sesuai rencana; sesuai kemampuan; sistem atau cara pengadaan sesuai ketentuan (Seto et al, 2012)

\section{Penerimaan Obat dan Penyimpanan Obat}

Penerimaan merupakan kegiatan untuk menjamin kesesuaian jenis, spesifikasi, jumlah, mutu, waktu penyerahan dan harga yang tertera dalam kontrak atau surat pesanan dengan kondisi fisik yang diterima.

Penyimpanan obat adalah proses dimana setelah barang diterima di instalasi farmasi dan sebelum akan dilakukan pendistribusian barang tersebut.

\section{Pendistribusian Obat}

Pendistribusian merupakan suatu rangkaian dalam rangka menyalurkan sediaan farmasi, alat kesehatan, BHP Medis dari tempat penyimpanan sampai kepada unit pelayananatau pasien dengan tetap menjamin mutu, stabilitas, jenis, jumlah, ketepatan waktu.

\section{Pemusnahan Obat}

Pemusnahan dilakukan untuk sediaan farmasi, alat kesehatan, dan bahan medis habis pakai bila produk tidak memenuhi persyaratan mutu, produk telah kadaluwarsa, produk tidak memenuhi syarat untuk dipergunakan dalam pelayanan kesehatan atau kepentingan ilmu pengetahuan, produk tersebut dicabut izin edarnya.

\section{Pencatatan dan Pelaporan}

Adminisitrasi harus dilakukan secara tertib dan berkesinambungan guna memudahkan penelusuran kegiatan yang sudah berlalu.Salah satu kegiatan administrasi yakni pencatatan dan pelaporan.

Manajemen obat merupakan kemampuan dari rumah sakit untuk mengoptimalkan dalam penggunaan obat. Manajemen obat dengan syarat lima ketepatan yakni tepat produk, tepat pasien, tepat waktu, tepat penggunaan dan tepat jumlah dapat menjamin keselamatan pasien. Ketepatan tersebut juga didampingi dengan tepat komunikasi, tepat alasan dan tepat pendokumentasian (Romero, 2013). 


\section{METODE}

Penelitian ini merupakan penelitian deskriptif observasional dengan desain cross sectional study.Unit analisis penelitian ini yakni Unit Logistik Instalasi Farmasi RS Siti Khodijah Sepanjang.Sumber informasi penelitian ini yakni Kepala Instalasi Farmasi, Kepala Ruang Logistik dan petugas pada unit logistik.Penelitian dilakukan di logistik farmasi RS Siti Khodijah Sepanjang pada bulan Desember 2015 hingga Mei 2016.Variabel yang diteliti dalam penelitian ini yakni metode dari kegiatan pengelolaan perbekalan sediaan farmasi obat yang mana terdiri dari perencanaan, pengadaan, penerimaan, penyimpanan, pendistribusian, pemusnahan dan penarikan, pencatatan dan pelaporan serta evaluasi.

Data primer didapatkan melalui wawancara dan observasi langsung di logistik instalasi farmasi RS Siti Khodijah Sepanjang. Observasi dilakukan dengan menggunakan lembar observasi dengan hasil pengukuran dikategorikan sebagai berikut penilaian baik (76\%-100\%), kurang baik (51\%-75\%), tidak baik (26\%-50\%), sangat tidak baik (0\%-25\%) dengan Cara perhitungan $=(\Sigma$ skor benar $):(\Sigma$ skor total) $\times 100 \%$. Wawancara dilakukan dengan menggunakan lembar panduan wawancara yang nantinya akan ditranskip sebagai dasar penunjang hasil observasi. Data sekunder diperoleh dengan melihat dokumen yang berkaitan dengan penelitian pada logistik instalasi farmasi rumah sakit studi dan beserta dokumen lain. Teknik analisis data yang digunakan pada penelitian ini yakni analisis data kualitatif yakni mencakup transkip hasil wawancara, reduksi data, analisis, interpretasi data dan
triangulasi.Dari hasil analisis data yang kemudian dapat ditarik kesimpulan.

\section{HASIL DAN PEMBAHASAN}

Pengelolaan Persediaan Obat Logistik Farmasi RS Siti Khodijah

Pengelolaan persediaan obat yang beredar di Rumah Sakit Siti Khodijah Sepanjang dilakukan dengan sistem satu pintu oleh Instalasi Farmasi RS Siti Khodijah Sepanjang.Instalasi Farmasi RS Siti Khodijah Sepanjang dipimpin oleh Kepala Instalasi Farmasi dengan pendidikan terakhir yakni sarjana apoteker.Logistik farmasi rumah sakit Siti Khodijah Sepanjang melaksanakan kegiatan pengelolaan sediaan obat berupa perencanaan, pengadaan, penerimaan, penyimpanan, pendistribusian, pemusnahan dan pengarsipan (pencatatan dan pelaporan).Komunikasi yang baik dari berbagai pihak yang terkait dalam melakukan pengelolaan obat dapat meningkatkan efektifitas pelaksanaan kegiatan tersebut (Rosmania and Supriyanto, 2015). Berikut persentase penilaian metode dalamproses pengelolaan obat di Rumah Sakit Slti Khodijah berdasarkan dengan Permenkes No. 58 Tahun 2014 dan teori: 
Tabel 1.Hasil Penilaian Kegiatan Pengelolaan Obat Di Rumah Sakit Siti Khodijah Sepanjang Tahun 2016

\begin{tabular}{lrr}
\hline & \multirow{2}{*}{ Kegiatan } & \multicolumn{1}{c}{ Kesesuaian } \\
\cline { 2 - 3 } & Sesuai & \multicolumn{1}{c}{ Tidak } \\
\hline Perencanaan & $50,00 \%$ & $50,00 \%$ \\
\hline Pengadaan & $80,00 \%$ & $20,00 \%$ \\
\hline Penerimaan & $85,71 \%$ & $14,29 \%$ \\
\hline Penyimpanan & $61,54 \%$ & $38,46 \%$ \\
\hline Pendistribusian & $80,00 \%$ & $20,00 \%$ \\
\hline Pemusnahan & $100,00 \%$ & $0,00 \%$ \\
\hline Pencatatan dan pelaporan & $69,23 \%$ & $30,77 \%$ \\
\end{tabular}

\section{Perencanaan Obat}

Perencanaan kebutuhan obat yang dilakukan Logistik Instalasi Farmasi RS Siti Khodijah Sepanjang yakni berupa perencanan bulanan obat yang dilakukan setiap akhir bulan. Perencanaan tahunan obat yakni didasarkan pada Rencana Bisnis Anggaran (RBA) tahunan RS Siti Khodijah Sepanjang dimana pendapatan berasal dari farmasi sebanyak lebih kurang $70-75 \%$ dari keseluruhan pendapatan rumah sakit pada satu tahun tersebut. Perencanaan bulanan obat yang dilakukan setiap satu bulan sekali yang nantinya akan dilakukan breakdown untuk perencanaan pembelian obat tersebut setiap minggunya. Metode yang digunakan logistik farmasi Rumah Sakit Siti Khodijah Sepanjang dalam merencanakan kebutuhan obat yakni kombinasi dari metode konsumsi pemakaian periode sebelumnya dan metode epidemiologi dengan 10 (sepuluh) trend penyakit yang berobat ke rumah sakit tersebut.

Pada Tabel 1 terlihat bahwa metode perencanaan obat dalam pelaksanaannya tergolong tidak baik $(50,00 \%)$. Dalam pelaksanaan kegiatan perencanaan dengan metode konsumsi, logistik farmasi belum melakukan perhitungan rata-rata pemakaian obat yang mana berarti belum melakukan tahapan perhitungan metode konsumsi secara sesuai. Cara perhitungan metode konsumsi untuk memperoleh data kebutuhan obat yang mendekati ketepatan yakni dengan melakukan perhitungan pemakaian rata-rata obat, buffer stock, lead time dan jumlah sisa obat yang ada (Irmawati, 2014). Selain itu pihak logistik obat yang mana sebagai petugas perencanaan tidak memiliki dokumen trend sepuluh penyakit sehingga dikatakan kurang efektif dalam menjalankan metode epidemiologi.

Perencanaan bulanan obat belum mempertimbangkan anggaran yang tersedia dimana berdasarkan Permenkes No, 58 Tahun 2014 tentang Standar Pelayanan Farmasi Rumah Sakit bahwa perencanaan harus mempertimbangkan beberapa hal yang salah satunya yakni anggaran yang tersedia. Tindakan pemantauan dan pengawasan atas obat-obat yang mahal dapat menghabiskan sekitar $20 \%$ biaya penyimpanan obat (Khant et al., 2015).

\section{Pengadaan Obat}

Pengadaan obat yang beredar pada Rumah Sakit Siti Khodijah Sepanjang dilakukan secara pembelian langsung kepada pihak distributor oleh salah satu petugas di ruang logistik. Pengadaan obat dilakukan setiap hari dengan perkiraan kedatangan 
obat akan sampai satu atau dua hari kemudian.Pengadaan obat rumah sakit studi yang dilakukan yakni tidak hanya berdasarkan lembar perencanaan namun juga dapat dilakukan diluar hasil dari perencanaan obat yang sudah dilakukan.Jumlah obat yang dilakukan pengadaan diluar perencanaan berdasarkan dari adanya permintaan obat dari unit pelayanan atau depo namun tidak dapat dilayani oleh logistik farmasi rumah sakit (stockout).

Berdasarkan Tabel 1 metode pengadaan obat dalam pelaksanaannya tergolong baik $(80,00 \%)$. Pengadaan obat yang dilakukan Logistik Instalasi Farmasi RS Siti Khodijah Sepanjang kurang menjamin expired date obat dimana obat yang dimaksudkan disini yakni obat selain jenis vaksin, reagenesia, dan lain-lain. Berdasarkan Permenkes No. 58 Tahun 2014 Tentang Standar Pelayanan Farmasi Rumah Sakit bahwa pengadaan obat merupakan kegiatan yang dimaksudkan untuk merealisasikan perencanaan kebutuhan. Pengadaan obat harus memperhatikan beberapa hal yang mana salah satu diantaranya yakni expired date minimal 2 (dua) tahun kecuali untuk sediaan farmasi jenis tertentu yakni vaksin, reagenesia dan lain-lain.

Pengadaan obat yang terjadi diluar perencanaan kebutuhan yang sudah ditetapkan yang mana belum memiliki batas yang pasti.Sehingga hal tersebut dapat menyebabkan terjadinya stagnant dan stockout obat akibat dari jumlah obat yang diadakan berlebihan atau kurang.

Pemesanan obat logistik farmasi Instalasi Farmasi Rumah Sakit Siti Khodijah Sepanjang melalui dua pilihan cara yakni menghubungi pihak distributor jika salesman tidak datang atau jika salesman datang maka surat pesanan akan diberikan saat itu juga. Penyerahan surat pesanan untuk pemesanan melalui telepon akan dilakukan saat pihak distributor akan melakukan penagihan pada bagian keuangan. Surat pesanan obat merupakan hal penting karena saat penerimaan perlu dilakukan pengecekkan kesesuaiannya dengan obat yang datang sehingga jika surat pesanan belakangan maka dapat menurunkan kontrol atas jumlah obat yang diterima. Selain itu surat pesanan juga dapat menjamin waktu ketersediaan obat tersebut dilihat dari tanggal dikeluarkan surat dan hinngga hari yang ditentukan obat belum datang dapat menghubungi pihak distributor. Hal ini dapat mempengaruhi tingkat persediaan obat menjadi stagnant dan stockout obat.

\section{Penerimaan Obat}

Metode penerimaan obat yang diterapkan pada logistik Instalasi Farmasi Rumah Sakit Siti Khodijah Sepanjang yakni dimana barang datang langsung dilakukan penyimpanan pada hari tersebut juga.Petugas melakukan pemeriksaan atas keadaan barang dan keabsahan faktur dengan obat yang datang.

Pada Tabel 1 metode penerimaan obat yang dijalankan sudah tergolong baik (85,71\%). Hal tersebut dapat dijelaskan karena penerimaan obat yang diterapkan dapat menjamin kesesuaian jenis, spesifikasi obat, jumlah, mutu dan harga obat serta dokumen penerimaan obat disimpan dengan baik.Akan tetapi terdapat hal yang belum dijalankan untuk menunjang penerimaan obat menjadi lebih baik lagi yakni mengatur tentang kesesuaian waktu 
penyerahan obat dari melakukan pemesanan hingga barang datang.

Berdasarkan Permenkes No. 58 Tahun 2014 Tentang Standar Pelayanan Farmasi Rumah Sakit bahwa penerimaan merupakan kegiatan untuk menjamin keseuaian jenis, spesifikasi, jumlah, mutu, waktu penyerahan dan harga yang tertera dalam kontak atau surat pesanan dengan kondisi fisik yang diterima. Dengan tidak dilakukannya pengecekkan atas kesesuaian surat pesanan maka kegiatan penerimaan menjadi kurang efektif karena tidak bisa menjamin obat yang datang memenuhi kriteria sesuai jenis, spesifikasi, jumlah, mutu, waktu penyerahan dan harga yang tertera dalam surat pesanan. Hal tersebut dapat berpengaruh terhadap kondisi jumlah obat menjadi stagnant dan stockout.

\section{Penyimpanan Obat}

Penyimpanan obat pada Instalasi Farmasi RS Siti Khodijah Sepanjang pada ruang logistik farmasi dengan persediaan di ruang (floor stock) pada depo farmasi 1 , depo farmasi 2 dan kamar obat di ruang rawat inap. Penyimpanan dipisahkan menurut jenis sediaan menggunakan prinsip kombinasi First In First Out (FIFO) dan First ExpiredFirst Out (FEFO). Penyimpanan obat pada ruang logistik farmasi berdasarkan jenis sediaan, kategori pasien (BPJS dan Umum) dan berdasarkan abjad nama obat. Floor stock pada Depo farmasi dibedakan pasien regular dan BPJS, lalu dibedakan berdasarkan farmakologi terapi obat tersebut dan selanjutnya diurutkan sesuai abjad nama obat. Penyimpanan obat pada ruang rawat inap yakni emergency kitdan stock tetap yang harus tersedia.
Metode penyimpanan obat dalam pelaksanaannya tergolong kurang baik $(61,54 \%)$. Hal ini dapat dijelaskan dengan terdapat beberapa hal yang belun dijalankan sebagai berikut penyimpanan obat pada ruang logistik farmasi masih terdapat beberapa obat yang tidak terdapat label nama obat, Berdasarkan Permenkes No. 58 Tahun 2014 bahwa komponen yang harus diperhatikan dalam penyimpanan obat antara lain obat dan bahan kimia yang digunakan diberi label yang secara jelas memuat nama, tanggal pertama kemasan dibuka, tanggal kadaluarsa dan peringatan khusus. Salah satu tujuan pengaturan penyimpanan obat yang baik agar obat-obat dapat diperoleh dengan mudah oleh petugas yang mana sebagai petugas penyimpanan obat (Siregar,2004). Sehingga jika masih terdapat beberapa obat yang tidak memiliki label nama obat tersendiri dapat menyulitkan pertugas dan memakan waktu lama dalam menemukan obat tersebut yang mana dapat mempengaruhi efektifitas kegiatan penyimpanan obat.

Data mengenai jumlah persediaan obat instalasi farmasi rumah sakit studi dilakukan secara komputerisasi.Tidak terdapat kartu stok pada setiap jenis obat yang ada baik di logistik maupun di ruang penyimpanan lainnya. Arsip stok merupakan inti dari sistem manajemen inventory dan beberapa sistem persediaan melakukan 2 (dua) jenis arsip stok berupa manual kartu beserta sistem komputer untuk setiap obat yang mana dapat menambah keakuratan dan keakuntabilitas (Management Science for Health, 2012).

Kepala Instalasi Farmasi belum memiliki jadwal secara menetap untuk melakukan 
pengontrollan pada penyimpanan persedian obat di ruang-ruang (floor stock) selain ruangan logistik farmasi. Menurut Permenkes No. 58 Tahun 2014, Instalasi Farmasi harus dapat memastikan bahwa obat disimpan secara benar dan dilakukan inspeksi secara periodik. Sehingga hal ini dapat memberi efek negatif pada kondisi obat dan dapat menimbulkan kejadian stagnant dan stockout obat.

\section{Pendistribusian Obat}

Metode pendistribusian obat yang dilakukan adalah dengan metode desentralisasi yaitu semua penyaluran obat ke unit-unit pelayanan terpusat pada gudang logistik disertai dengan penyediaan obat-obat tertentu di kamar obat pada rawat inap dan depo farmasi.Pendistribusian obat untuk pasien rawat inap yakni menggunakan dengan sistem kombinasi Unit Dose Dispensing (UDD) dan resep perorangan sementara untuk pasien rawat jalan yakni dengan sistem resep perorangan. Proses pendistribusian obat yang dilakukan di logistik instalasi farmasi yakni dengan prinsip First In First Out (FIFO) yakni dimana obat yang dikeluarkan adalah obat yang pertama kali datang. Tidak ada petugas khusus dalam pendistribusian obat melainkan para penanggung jawab tiap unit pelayanan, kamar obat, dan depo mengambil sendiri ke ruangan logistik farmasi.

Metode pendistribusian obat sudah tergolong baik dalam pelaksanaannya (80\%).Namun masih terdapat satu hal yang belum berjalan dengan baik yakni saat observasi terdapat pendistribusian obat tanpa menyerahkan bon permintaan terlebih dahulu.Pendistribusian obat yang dilakukan di logistik farmasi Instalasi Farmasi RS Siti Khodijah
Sepanjang terkadang dilakukan tanpa penyerahan bon permintaan terlebih dahulu.Siklus distribusi berisi langkah-langkah yang terdiri dari adanya permintaan atas persediaan (obat), pengiriman, penggunaan pada pasien, dan pelaporan atas pengkonsumsian (Management Science for Health, 2012). Sehingga penyaluran obat atau pendistribusian obat dari ruang logistik ke unit pelayanan lain akan lebih baik jika menggunakan bon permintaan terdahulu agar mampu menabah efektif dan efisiensi kegiatan distribusi obat. Selain itu bon permintaan juga sebagai dasar untuk melakukan pencatatan obat keluar, sehingga jika tidak menggunakan bon permintaan dapat menurunkan kualitas pencatatan pemakaian obat dan dapat memberi efek terjadinya stagnant dan stockout obat.

Bon permintaan disini berfungsi sebagai lembar pemakaian dan lembar permintaan obat (LPLPO). Berdasarkan penelitian Winarso (1999) bahwa LPLPO obat jika dilakukan dengan baik maka akan dapat meningkatkan efisiensi dari manajamen obat suatu rumah sakit. Sisa stok dalam bon permintaan dapat digunakan sebagai dasar pemantauan jumlah persediaan obat yang dapat menurunkan kejadian adanya stagnant dan stockout obat.

\section{Pemusnahan dan Penarikan Obat}

Metode pemusnahan obat yang dilakukan pada Instalasi Farmasi RS Siti Khodijah Sepanjang adalah bekerja sama dengan pihak ke-3 dikarenakan incenerator yang dimiliki dalam keadaan rusak. Obat-obat yang kadaluarsa dan rusak akan dikumpulkan dan selanjutnya dilakukan pemusnahan 
disertai dengan Berita Acara Pemusnahan (BAP). Pemusnahan obat dilakukan setiap enam bulan sekali setelah melakukan stock opname besar. Obat yang tidak memenuhi kualitas atau persyaratan atas dasar pembritahuan resmi dari pihak distributor dan atas dasar terdapat incident di rumah sakit akibat obat tersebut akan ditarik dari penyimpanan kemudian dikembalikan kepada pihak distributor.

Kegiatan pemusnahan obat yang dilakukan di Instalasi Farmasi RS Siti Khodijah Sepanjang kategori baik (100\%) yang terlihat pada Tabel 1 karena sudah berjalan sesuai dengan peraturan yang ada. Pemusnahan obat yang dilakukan Instalasi Farmasi RS Siti Khodijah Sepanjang yakni menggunakan jasa pihak ke-3.Kualitas pihak ke-3 dalam pemusnahan obat dijamin dengan dokumen MOU antara rumah sakit dengan perusahaan tersebut.

\section{Pencatatan dan Pelaporan}

Pencatatan dan pelaporan mengenai pengelolaan persediaan obat yang dilakukan oleh logistik Instalasi Farmasi RS Siti Khodijah Sepanjang yakni meliputi kegiatan perencanaan, pengadaan, penerimaan, penyimpanan, pendistribusian, pemusnahan, dan pengendalian persediaan obat.

Berdasarkan Tabel 1 dapat diketahui bahwa kegiatan pencatatan dan pelaporan obat tergolong kurang baik $(69,23 \%)$ karena masih terdapat beberapa hal yang belum dilakukan yakni belum melakukan pencocokkan jumlah fisik dengan jumlah dalam sistem komputerisasi. Perhitungan secara fisik jumlah obat yang tersedia dengan jumlah yang ada dalam sistem komputer belum dilakukan secara berkala hanya jika terjadi missing pada suatu
waktu.Perhitungan jumlah fisik secara berkala penting untuk dilakukan. Menurut penelitian Yuliasari (2008) pencocokkan jumlah fisik persediaan dengan jumlah persediaan obat system inventory atau sistem komputer merupakan salah satu cara pengendalian persediaan obat.

Pencatatan suhu yang dilakukan di ruang logistik Instalasi Farmasi RS Siti Khodijah Sepanjang hanya dilakukan untuk suhu lemari pendingin (freezer) dengan waktu setiap pagi dan sore.Pencatatan suhu ruangan tidak dilakukan walaupun sudah tersedia alat pengukur suhu dan kelembapan udara.Suhu gudang penyimpanan obat sangat berperan dalam menjaga umur sediaan farmasi berupa obat (Palupiningtyas, 2014). Kondisi ruang penyimpanan obat merupakan hal yang kritis dikarenakan terdapat beberapa obat yang memiliki karakteristik sensitif terhadap panas dan rusak akibat perubahan temperature sehingga sangat penting untuk memantau level suhu walau ruangan sudah menggunakan pendingin dan freezer (Kagashe and Massawe, 2012).

Pelaporan tahunan yang dilakukan Instalai Farmasi RS Siti Khodijah yakni berupa "Laporan Review Perbekalan Farmasi" yang berisi jumlah obat yang stagnant dan stockout beserta nilai kerugian yang dialami namun dalam laporan tersebut belum terdapat data mengenai jumlah obat yang berkategori $A$ atas hasil analisis $A B C$ yang dilakukan. Alat yang baik digunakan untuk melihat pergerakan stok adalah Analisis $A B C$ yang mana mengkategorisasi item berdasarkan jumlah dan nilai dari pemakaian selama periode waktu tertentu (Management Science for Health, 2012) sehingga 
analisis $\mathrm{ABC}$ dan hasilnya dapat membantu pengendalian persediaan obat serta menurunkan resiko kejadian stagnant dan stockout obat.

\section{Evaluasi Pengelolaan Persediaan Farmasi}

Evaluasi yang dilakukan Instalasi Farmasi RS

Siti Khodijah Sepanjang yakni dengan audit keuangan yang mana membandingkan hasil dengan rencana yang telah tersusun selama periode satu tahun. Audit keuangan dilakukan oleh Tim SPI Rumah Sakit Siti Khodijah Sepanjang dimana dilakukan setelah program dijalankan sehingga jenis evaluasi yang dilakukan yakni retrospektif. Namun evaluasi yang dijalankan dirasa kurang cukup karena dalam rangka mengendalikan dan meningkatkan mutu pelayanan evaluasi harus mencakup seluruh proses pengukuran dan penilaian atas semua kegiatan Pelayanan Farmasi di Rumah Sakit secara berkala.

Berdasarkan Permenkes No. 58 Tahun 2014 Tentang Standar Pelayanan Farmasi di Rumah Sakit evaluasi merupakan suatu penilaian secara terencana, sistematis, dan teroganisir dimana sebagai umpan balik perbaikan sistem. Tujuan evaluasi yakni dalam rangka meningkatkan dan mengendalikan mutu pelayanan instalasi farmasi. Evaluasi harus dilaksanakan terhadap seluruh proses tata kelola sediaan farmasi, alat kesehatan dan bahan medis habis pakai sesuai ketentuan yang berlaku. Instalasi Farmasi memerlukan untuk melakukan evaluasi terhadap kinerja pegawai ruang logistik, survey konsumen, dan penilaian terhadap pelayanan kefarmasian yang diberikan.

\section{SIMPULAN}

Pelaksanaan metode dalam perencanaan, penyimpanan dan pencatatan serta pelaporan terhadap pengelolaan persediaan obat Rumah Sakit Siti Khodijah Sepanjang belum tergolong kategori baik.Pelaksanaan yang tidak baik dari kegiatan tersebut dapat mempengaruhi efektifitas kegiatan pengelolaan persediaan obat Rumah Sakit Siti Khodijah Sepanjang.Efektifitas dan efisiensi dari kegiatan pengelolaan persediaan obat mempengaruhi kejadian stagnant dan stockout obat. Logistik farmasi RS Siti Khodijah Sepanjang memerlukan pengkajian dalam menerapkan metode perhitungan jumlah obat yang direncanakan untuk periode selanjutnya serta mengkaji ulang terhadap kegiatan pengadaan obat tanpa menyerahkan surat pesanan sebelum obat tersebut datang. Instalasi farmasi mengeluarkan beberapa ketentuan yakni menetapkan batas untuk jumlah pengadaan obat diluar perencanaan obat yang telah disusun dan jadwal kegiatan untuk melakukan kunjungan pengontrollan ke penyimpanan obat yang diluar ruang logistik. Instalasi Farmasi Rumah Sakit Siti Khodijah Sepanjang perlu melakukan evaluasi manajemen terhadap seluruh kegiatan pengelolaan logistik dimulai dari perencanaan hingga pencatatan dan pelaporan

\section{DAFTAR PUSTAKA}

Anshari, M.(2009).Aplikasi Manajemen Pengelolaan Obat dan Makanan, Yogyakarta: Nuha Litera Offset.

Febreani, Stella H. (2016). Pengendalian Persediaan Obat Pada Logistik Farmasi Rumah Sakit Siti Khodijah Sepanjang. Skripsi. Universitas Airlangga

Irmawati(2014).Manajemen Logistik Farmasi Di Rumah Sakit Pedoman Buku Ajar S1 
Adimistrasi Rumah Sakit.Tersedia di:https://books.google.co.id [12 Desember 2015].

Kagashe, G.A.B. and Massawe, T. (2012). Medicine Stock Out and Inventory Management Problems in Public Hospital in Tanazia: A Case of DAR E SALAAM Region Hospitals. International Journal of Pharmacy, Vol.II, No.2, February, pp.252-259.

Khant,S., Haldar, P., Singh, A. and Kankaria, A. (2015). Inventory Management of Drugs at a Secondary Level Hospital.Journal of Young Pharmacist.Vol.7, No.2, April-June, pp.113117.

Management Science for Health (2012) Managing Acces to Medicines and Health Technologies (MDS-3), $3^{\text {rd }}$ edition, Management Science for Health Inc.

Mellen, Renie.C and Pudjirahardjo, Widodo J. (2013).Faktor Penyebab Dan Keugian Akibat Stockout Dan Stagnant Obat Di Unit Logistik RSU Haji Surabaya.Jurnal Administrasi Kesehatan Indonesia.Vol.1, No.1, JanuariMaret, pp.99-107.

Palupiningtyas, Retno.(2014). Analisis sistem penyimpanan obat di gudang farmasi rumah sakit mulya tangerang.Skripsi.Universitas Islam Negeri Syarif Hidayatullah.

Peraturan Menteri Kesehatan Nomor 58 Tahun 2014 Tentang Standar Pelayanan Farmasi Rumah Sakit.Jakarta:Kementerian Kesehatan.

Romero, Alejandro. (2013). Managing Medicines in the Hospital Pharmacy: Logistics Inefficiencies. Journal Word Congress on
Engineering and Computer Science 2013.Vol.2, pp.1120-1125.

Rosmania, Fenty A. and Supriyanto, Stefanus.(2015). Analisis Pengelolaan Obat Sebagai Dasar Pengendalian Safety StockPada Stagnant Dan Stockout Obat.Jurnal Administrasi Kesehatan Indonesia.Vol.3, No.1, Januari-Juni, pp.1-9.

Seto, S., Nita, Y., Triana, L. (2012). Manajemen Farmasi Lingkup: Apotek, Farmasi, Rumah Sakit, Pedagang Besar Farmasi, Instalasi Farmasi. Edisi Tiga. Surabaya: Airlangga University Press.

Siregar, C.J.P. (2004). Farmasi Rumah Sakit Teori dan Terapan, Jakarta: EGC.

Verawaty, D.M., Damayanti, D.D. dan Santosa, B. (2010). Perencanaan Kebijakan Persediaan Obat Dengan Menggunakan Metode Probabilistik Continous Review (S,S) System Pada Bagian Instalasi Farmasi RS AMC, Teknik Industri Universitas Telkom, pp. 1-6.

Winarso, Agus.,(1999). Evaluasi Manfaat Penerapan Laporan Pemakaian Lembar Permintaan Obat (LPLPO) Untuk Meningkatkan Efisiensi Perencanaan Obat Di Gudang Farmasi Kabupaten Klaten.Tesis. Universitas Gajah Mada. Tersedia di $<$ http://etd.repository.ugm.ac.id/index.php?mo $\mathrm{d}=\quad$ penelitian detail \& sub=PenelitianDetail\&act=view\&typ=html\&bu ku_id=4407>[02 Juni 2016].

Yuliasari, (2008).Pengendalian Persediaan Obat Generik melalui Metode Analisis ABC, di Gudang Farmasi RS Jantung dan Pembuluh Darah Harapan Kita Jakarta tahun 2008.Skripsi.Universitas Indonesia. 